\title{
Validation of nursing outcome content Fall prevention behavior in a hospital environment
}

\author{
Validação de conteúdo do resultado de enfermagem Comportamento de prevenção de \\ quedas em ambiente hospitalar
}

Jéssica Naiara de Medeiros Araújo ${ }^{1}$, Ana Paula Nunes de Lima Fernandes ${ }^{1}$, Laísla Alves Moura ${ }^{1}$, Marina Marisa Palhano dos Santos ${ }^{1}$, Marcos Antonio Ferreira Júnior ${ }^{1}$, Allyne Fortes Vitor ${ }^{1}$

Objective: to validate the contents of the nursing outcome Fall prevention behavior of the Nursing Outcomes Classification in hospitalized patients. Methods: this is a content validation research. Psychometry was used as an operational method. The Nursing Outcome was validated by 16 specialists. A Content Validity Index was applied with its binomial test to evaluate the indicators in the psychometric criteria. Results: from the experts' assessment of the constitutive, operational and operational magnitude of the indicators, the need for adequacy was found in the indicators. It controls the restlessness, it carries out precautions when taking drugs that increase the risk of falls and it adequately use chairs. Conclusion: it was found that the indicators were considered mostly valid as to the content. Therefore, they were able to measure the prevention behavior of falls in the hospital environment.

Descriptors: Validation Studies; Outcome Assessment (Health Care); Accidental Falls; Nursing Process; Nursing.

Objetivo: validar o conteúdo do resultado de enfermagem Comportamento de prevenção de quedas da taxonomia Nursing Outcomes Classification em pacientes internados em ambiente hospitalar. Métodos: trata-se de uma pesquisa de validação de conteúdo. Utilizou-se a Psicometria como método operacional. O Resultado de Enfermagem foi validado por 16 especialistas. Aplicou-se Índice de Validade do Conteúdo com respectivo teste binomial com objetivo de avaliar os indicadores com relação aos critérios psicométricos. Resultados: a partir da avaliação dos especialistas quanto à definição constitutiva, operacional e magnitude operacional dos indicadores, encontrou-se a necessidade de adequação em relação aos indicadores Controla a inquietação, Executa precauções ao tomar medicamentos que aumentam o risco de quedas e Utiliza adequadamente cadeiras. Conclusão: constatou-se que os indicadores foram considerados em sua maioria válidos quanto ao conteúdo e, portanto, capazes de mensurar o comportamento de prevenção de quedas no ambiente hospitalar.

Descritores: Estudos de Validação; Avaliação de Resultados (Cuidados de Saúde); Acidentes por Quedas; Processo de Enfermagem; Enfermagem.

\footnotetext{
${ }^{1}$ Universidade Federal do Rio Grande do Norte. Natal, RN, Brazil. 


\section{Introduction}

Falls are considered of great severity due to the impact on health, especially in hospitalized patients. In this scenario, it is essential to implement actions to ensure a safe environment throughout hospitalization, with emphasis on risk measurement and prevention of injuries ${ }^{(1)}$.

The guarantee of a safe environment becomes an indicator of quality control since the occurrence of falls during hospitalization is most often responsible for an increase in hospitalization time and consequent delay in recovery ${ }^{(2)}$. Evaluated as one of the main adverse events occurring in hospital institutions, its consequences can result from mild bruising, bruising, fractures and trauma to death. Also, they can proceed in psychological damages especially in elderly patients $^{(2-4)}$.

In this context, a survey performed in a hospital environment shows an average of 1.37 falls per 1,000 patients per day ${ }^{(3)}$. Another study performed with hospitalized elderly patients estimated an incidence of falls of 12.6 per 1,000 patients per day ${ }^{(5)}$. For this, the incidence of falls is considered as an important indicator of the quality of care and, in particular, of patient safety ${ }^{(6)}$.

When considering the importance of quality of care and patient safety in health institutions, especially in the prevention of falls, it is relevant to evaluate and validate instruments to assess the risk of patients for the formulation of preventive measures and quality assurance of nursing $\operatorname{care}^{(7)}$. This inquiry requires an organization of nursing work because the Nursing Care Systematization is presented and its Classification Systems are highlighted as tools that guide the work process.

In this sense, the Nursing Outcomes Classification (NOC) is highlighted, as it has evaluation properties of the individual's health status, especially nursing results related to Nursing Diagnosis of Risk of falls. In this way, it acts as a tool for the management of falls. In this study, the Nursing Outcome of Fall Prevention
Behavior is highlighted, part of the Knowledge of Health and Behavior domain and in the Risk and Safety Control $\operatorname{class}^{(8)}$.

Thus, it is perceived that more accurate instruments for assessing health status are required, especially regarding patient safety. Thus, it is imperative to validate parameters to measure the risk of adverse events and the state of health of the individuals, in agreement with the standardized nursing language ${ }^{(9)}$.

There are other instruments aimed at assessing the risk of falls. However, this scale belonging to the NOC taxonomy is innovative because it uses the specific language of nursing ${ }^{(10-12)}$. It is relevant to the profession and advances in knowledge in the state of the art since the use of the standardized language through the NOC transmits the essence of nursing care and helps in the improvement of the professional practice through the research, besides promoting greater visibility in the health policy scenario ${ }^{(8)}$. Therefore, there is the following guiding question: Is the Nursing Outcome of fall prevention behavior validated for the content of hospitalized patients?

Therefore, the aim of this study was to validate the content of the Nursing Outcome of fall prevention behavior of the Nursing Outcomes Classification taxonomy in patients hospitalized in a hospital setting.

\section{Methods}

This is a methodological validation research carried out from May to July 2013. For this purpose, Psychometrics was used as an operational method to determine which indicators, constitutive, operational definitions, and operational magnitudes could represent the content of the intended construct and which should be excluded ${ }^{(13)}$.

An adjustment of the scoring system or criteria for the definition of expertise was used to search and select nurses able to participate ${ }^{(14)}$, in which the criterion of nursing was adopted as the common minimum. The identification of these experts was done using snowball type sampling, with professional indi- 
cations and by searching the Lattes Platform, available on the National Council of Scientific and Technological Development portal. The following keywords were used: clinical nursing, surgical nursing, and patient safety.

The curricula were analyzed from the titration, professional experience, participation in research projects and bibliographic production. Thus, 101 specialists were selected. Only 92 of them were contacted by their respective electronic addresses due to the lack of identification information of the individuals, preventing the initial contact. Then, an invitation letter was sent to each specialist with information about the title, purpose of the research and the purpose of the study participation. There were 16 specialists answering the evaluation of the instrument in an integral and timely manner. Thus, corresponded to the final sample.

In this sense, the sample was selected by intentionality with the inclusion of nurses with a degree/ experience in research, teaching or assistance in clinical nursing care and/or nursing terminology and/ or on accidents due to falls/patient safety, to judge the adequate content of the instrument.

The instructions addressed the criteria to be considered in the evaluation of the instrument, based on Psychometrics ${ }^{(13)}$. Thus, the specialists evaluated the instrument according to the same criteria used for its construction: criterion of behavioral, criterion of simplicity, criterion of clarity, criterion of relevance, criterion of accuracy, criterion of typicity and criterion of amplitude.

It is worth emphasizing that Psychometry proposes 12 specific criteria ${ }^{(13)}$. However, the above criteria were considered by the researchers who built the instrument as enough to measure the validity of content.

The instrument submitted to the evaluation of its content covered 20 items (indicators) of the Nursing Outcome Fall prevention behavior pertaining to the NOC taxonomy and their respective constitutive, operational and operational magnitudes performed in a previous study, coded by a numerical value in the following order: 1- Correctly using auxiliary mechanisms to wander; 2. Asking for physical assistance for him; 3- Using barriers to prevent falls during bedtime; 4- Using handrails as needed; 5- Keeping the environment free of accumulation of objects and obstacles and liquids on the floor; 6- Properly using stool and ladder; 7- Using adequate footwear to prevent falls; 8Adapting the height of the toilet as needed; 9- Properly using chairs; 10- Using the bed properly; 11- Properly using rubber mats on the tub floor/shower box; 12- Using safety bars in the bathroom to support the hands; 13- Controlling restlessness; 14- Taking caution when taking medicines that increase the risk of falls; 15- Adequately using vision correction features; 16- Using safe actions during the transfer; 17- Using the alarm system correctly; 18- Managing urinary/ intestinal urgency; 19- Using clothes of adequate size and 20-Correctly using hearing correction devices.

In this way, the experts evaluated the indicators, their respective constitutive, operational definitions and operational magnitudes such as - 1 (not adequate) or +1 (criteria met, that is, appropriate item).

The information concerning the evaluations were extracted and stored in a spreadsheet of the program Microsoft Excel 2012 to perform the analysis of the agreement of the specialists on the adequacy of the instrument content to the psychometric criteria adopted, containing the order of the specialists and their respective notes for each component of the instrument, according to each criterion judged. Then, the arithmetic mean of each criterion was calculated from the sum of the notes of the item by the number of specialists.

These data were imported into the Statistical Package for Social Sciences software version 20.0. A Content Validity Index was applied with its binomial test to evaluate the indicators in the psychometric criteria. The Content Validity Index (CVI) was evaluated with a cutoff point of 0.85 . For the purpose of this binomial analysis, the level of significance (p) of 0.05 was considered. 
The study complied with the formal requirements contained in the national and international regulatory standards for research involving human beings.

\section{Results}

From the evaluation of the 16 specialists on the Nursing Outcome of falls prevention behavior, is exposed to follow the judgment through the index of agreement of the experts regarding the adherence of the constitutive, operational definitions and operational magnitudes in relation to the psychometric criteria.

Table 1 shows the proportion of specialists who indicated the adherence of the definitions of indicators, based on the psychometric criteria.

In the constitutive definition of the indicators, for a level of significance of $5.0 \%$, there is the indicator Controlling the restlessness (13) with proportions less than $85.0 \%$ statistically significant regarding the criteria: clarity, precision, typicity, and amplitude.
The data regarding the adequacy of the adherence to the operational definitions of the indicators according to experts' assessment is presented in Table 2.

In the operational definition of indicators, at a significance level of $5.0 \%$, there are the indicators (13) Controlling the restlessness, (14) Taking caution when taking medications that increase the risk of falls, and (9) appropriately using chairs with lower ratios to $85 \%$ statistically significant. Indicator 13 presented a level of significance with all psychometric criteria, the indicator 14 presented level of significance with simplicity and accuracy criteria, while indicator nine with the criterion accuracy.

In the evaluation of the specialists regarding the operational magnitude of the indicators, according to Table 3, for a significance level of $5.0 \%$, there was the indicator (13) Controling the restlessness with proportions less than $85.0 \%$ statistically significant with all the criteria evaluated.

Table 1 - Evaluation of the specialists regarding the constitutive definition of the indicators when considering the psychometric criteria

\begin{tabular}{|c|c|c|c|c|c|c|c|}
\hline \multirow{2}{*}{ Indicators } & \multicolumn{7}{|c|}{ Criteria evaluated } \\
\hline & Behavior & Simplicity & Clarity & Relevance & Accuracy & Typicity & Amplitude \\
\hline 1 & 100.0 & 100.0 & 93.7 & 100.0 & 100.0 & 100.0 & 100.0 \\
\hline 2 & 100.0 & 100.0 & 93.7 & 100.0 & 75.0 & 87.5 & 87.5 \\
\hline 3 & 87.5 & 81.2 & 75.0 & 87.5 & 75.0 & 81.2 & 81.2 \\
\hline 4 & 87.5 & 87.5 & 87.5 & 68.7 & 87.5 & 87.5 & 87.5 \\
\hline 5 & 93.7 & 81.2 & 87.5 & 93.7 & 81.2 & 93.7 & 93.7 \\
\hline 6 & 100.0 & 100.0 & 100.0 & 100.0 & 100.0 & 100.0 & 100.0 \\
\hline 7 & 93.7 & 87.5 & 100.0 & 100.0 & 87.5 & 93.7 & 93.7 \\
\hline 8 & 93.7 & 93.7 & 93.7 & 93.7 & 93.7 & 93.7 & 93.7 \\
\hline 9 & 93.7 & 87.5 & 87.5 & 87.5 & 87.5 & 87.5 & 87.5 \\
\hline 10 & 100.0 & 93.7 & 93.7 & 93.7 & 93.7 & 93.7 & 93.7 \\
\hline 11 & 87.5 & 87.5 & 81.2 & 93.7 & 87.5 & 87.5 & 93.7 \\
\hline 12 & 100.0 & 93.7 & 93.7 & 100.0 & 100.0 & 93.7 & 93.7 \\
\hline 13 & 75.0 & 68.7 & $62.5^{*}$ & 68.7 & $62.5^{*}$ & $62.5^{*}$ & $62.5^{*}$ \\
\hline 14 & 87.5 & 87.5 & 87.5 & 87.5 & 87.5 & 8,5 & 87.5 \\
\hline 15 & 93.7 & 93.7 & 93.7 & 93.7 & 93.7 & 9.37 & 93.7 \\
\hline 16 & 93.7 & 81.2 & 81.2 & 93.7 & 87.5 & 87.5 & 87.5 \\
\hline 17 & 87.5 & 87.5 & 87.5 & 87.5 & 87.5 & 87.5 & 87.5 \\
\hline 18 & 87.5 & 75.0 & 81.2 & 87.5 & 87.5 & 87.5 & 87.5 \\
\hline 19 & 93.7 & 93.7 & 93.7 & 93.7 & 93.7 & 93.7 & 93.7 \\
\hline 20 & 93.7 & 93.7 & 93.7 & 93.7 & 93.7 & 93.7 & 93.7 \\
\hline
\end{tabular}


Table 2 - Expert assessment of the operational definitions of the indicators when considering the psychometric criteria

\begin{tabular}{|c|c|c|c|c|c|c|c|}
\hline \multirow{2}{*}{ Indicatores } & \multicolumn{7}{|c|}{ Criteria evaluated } \\
\hline & Behavior & Simplicity & Clarity & Relevance & Accuracy & Typicity & Amplitude \\
\hline 1 & 87.5 & 75.0 & 75.0 & 81.2 & 68.7 & 87.5 & 81.2 \\
\hline 2 & 93.7 & 93.7 & 87.5 & 93.7 & 75.0 & 93.7 & 87.5 \\
\hline 3 & 81.2 & 87.5 & 75.0 & 87.5 & 75.0 & 81.2 & 75.0 \\
\hline 4 & 87.5 & 87.5 & 87.5 & 87.5 & 81.2 & 87.5 & 87.5 \\
\hline 5 & 93.7 & 87.5 & 87.5 & 93.7 & 87.5 & 93.7 & 87.5 \\
\hline 6 & 100.0 & 100.0 & 93.7 & 100.0 & 100.0 & 100.0 & 93.7 \\
\hline 7 & 100.0 & 93.7 & 100.0 & 100.0 & 87.5 & 93.7 & 93.7 \\
\hline 8 & 93.7 & 93.7 & 93.7 & 93.7 & 93.7 & 93.7 & 93.7 \\
\hline 9 & 93.7 & 81.2 & 75.0 & 87.5 & $62.5^{*}$ & 81.2 & 81.2 \\
\hline 10 & 100.0 & 87.5 & 93.7 & 93.7 & 93.7 & 93.7 & 93.7 \\
\hline 11 & 87.5 & 87.5 & 81.2 & 93.7 & 87.5 & 87.5 & 87.5 \\
\hline 12 & 100.0 & 100.0 & 100.0 & 100.0 & 100.0 & 100.0 & 93.7 \\
\hline 13 & $62.5^{*}$ & $56.2^{* *}$ & $50.0^{* *}$ & $56.2^{* *}$ & $56.2^{* *}$ & $56.2^{* *}$ & $50.0^{* *}$ \\
\hline 14 & 75.0 & $62.5^{*}$ & 81.2 & 75.0 & $62.5^{*}$ & 75.0 & 68.7 \\
\hline 15 & 93.7 & 87.5 & 87.5 & 93.7 & 87.5 & 93.7 & 93.7 \\
\hline 16 & 100.0 & 81.2 & 81.2 & 93.7 & 81.2 & 93.7 & 93.7 \\
\hline 17 & 81.2 & 81.2 & 81.2 & 81.2 & 81.2 & 81.2 & 81.2 \\
\hline 18 & 87.5 & 81.2 & 87.5 & 93.7 & 87.5 & 93.7 & 93.7 \\
\hline 19 & 87.5 & 81.2 & 87.5 & 87.5 & 87.5 & 93.7 & 93.7 \\
\hline 20 & 87.5 & 87.5 & 87.5 & 81.2 & 81.2 & 81.2 & 81.2 \\
\hline
\end{tabular}

Table 3 - Evaluation of the specialists regarding the operational magnitude of the indicators when considering the psychometric criteria

\begin{tabular}{|c|c|c|c|c|c|c|c|}
\hline \multirow{2}{*}{ Indicatores } & \multicolumn{7}{|c|}{ Criteria evaluated } \\
\hline & Behavior & Simplicity & Clarity & Relevance & Accuracy & Typicity & Amplitude \\
\hline 1 & 93.7 & 87.5 & 81.2 & 87.5 & 81.2 & 87.5 & 81.2 \\
\hline 2 & 100.0 & 100.0 & 93.7 & 100.0 & 93.7 & 100.0 & 93.7 \\
\hline 3 & 87.5 & 87.5 & 87.5 & 87.5 & 81.2 & 81.2 & 81.2 \\
\hline 4 & 93.7 & 87.5 & 93.7 & 87.5 & 81.2 & 87.5 & 87.5 \\
\hline 5 & 93.7 & 87.5 & 93.7 & 93.7 & 93.7 & 93.7 & 87.5 \\
\hline 6 & 100.0 & 100.0 & 100.0 & 100.0 & 100.0 & 100.0 & 100.0 \\
\hline 7 & 100.0 & 93.7 & 93.7 & 100.0 & 93.7 & 100.0 & 93.7 \\
\hline 8 & 93.7 & 93.7 & 93.7 & 93.7 & 93.7 & 93.7 & 93.7 \\
\hline 9 & 93.7 & 87.5 & 81.2 & 93.7 & 87.5 & 87.5 & 87.5 \\
\hline 10 & 100.0 & 93.7 & 93.7 & 100.0 & 100.0 & 100.0 & 100.0 \\
\hline 11 & 87.5 & 81.2 & 75.0 & 93.7 & 81.2 & 87.5 & 87.5 \\
\hline 12 & 93.7 & 93.7 & 87.5 & 93.7 & 93.7 & 93.7 & 93.7 \\
\hline 13 & $62.5^{*}$ & $56.2^{* *}$ & $62.5^{*}$ & $62.5^{*}$ & $56.2^{* *}$ & $56.2^{* *}$ & $62.5^{(*)}$ \\
\hline 14 & 87.5 & 81.2 & 75.0 & 87.5 & 81.2 & 87.5 & 87.5 \\
\hline 15 & 93.7 & 87.5 & 81.2 & 93.7 & 87.5 & 93.7 & 93.7 \\
\hline 16 & 100.0 & 87.5 & 87.5 & 100.0 & 87.5 & 93.7 & 93.7 \\
\hline 17 & 81.2 & 81.2 & 81.2 & 81.2 & 81.2 & 81.2 & 81.2 \\
\hline 18 & 87.5 & 81.2 & 81.2 & 87.5 & 81.2 & 87.5 & 81.2 \\
\hline 19 & 93.7 & 87.5 & 87.5 & 93.7 & 87.5 & 100.0 & 93.7 \\
\hline 20 & 93.7 & 93.7 & 93.7 & 87.5 & 81.2 & 81.2 & 81.2 \\
\hline
\end{tabular}




\section{Discussion}

When considering the need for refinement of the Nursing Outcome for Fall Prevention Behavior in the hospital environment, it can be perceived the real relevance of the content validation of its definitions and magnitudes of its indicators by specialists in the theme and, above all, in the study of taxonomies of nursing. This refinement allows the improvement of the nursing language and the execution of the planning and implementation of interventions in a guided way to identify which preventive behaviors need special care. In this way, it ensures the execution of appropriate actions for the individual ${ }^{(15)}$.

Preventive behavior refers to the potential to exert control over modifiable risk factors through the use of strategies allowing an adaptation process with a focus on a healthier lifestyle. This individual capacity consists of individual skills, knowledge, and attitudes necessary to favor patient autonomy in identifying risks, making decisions and forming their support network. Nursing plays an important role in the development of this behavior, guaranteeing means that allow the individual to acquire the skills required for the correct management of risk factors, with an emphasis on prevention ${ }^{(16)}$.

It should be emphasized that the following discussion will be based on the indicators that presented statistical significance suggestive of modification in the constitutive, operational definitions and operational magnitudes according to the evaluation regarding the psychometric criteria.

Thus, based on the experts' assessment of the constitutive, operational and operational magnitude of the indicators, the need for adequacy was found for the indicators of Controling the restlessness, Taking caution when taking medicines that increase the risk of falls and Using the chairs adequately.

Concerning the indicator of Controlling the restlessness, the experts recommended the importance of adjustments related to the criteria clarity, accuracy, typicity and amplitude for the constitutive definition and to all the criteria regarding the operational definition and operational magnitude to be a better fit in the evaluation of the prevention behavior of falls in a hospital environment.

The definition of this indicator refers to the spontaneous control or the use of strategies allowing the control or prevention of the sensation of restlessness. The nurse should identify signs of restlessness and observe if the patient performs some breathing or relaxation technique, distraction activities or uses medications that reduce restlessness ${ }^{(8)}$. The restlessness may refer to the agitation presented by some patients, especially in a hospital environment. Regarding this, other studies performed in hospitals show agitation as a risk factor for falls ${ }^{(1-3)}$. In this way, the importance of this indicator is understood and the best clarification when considering the psychometric criteria for its constitutive, operational definition and operational magnitude.

According to the indicator Taking caution when taking medicines that increase the risk of falls, the specialists pointed out the need to adapt the operational definition according to the criteria simplicity and accuracy. Adjustments are imperative to ensure a simpler operational definition ensuring a unique meaning and make sure that it is unique in the measurement of this indicator when considering the numerous drugs that have predisposing effects to falls.

A study reports that the medication plan used during hospitalization is an important risk factor for falls ${ }^{(17)}$. Other review research has shown that the use of many medications, especially diuretics and benzodiazepines, is a potential risk factor for falls. Diuretics because they cause effects such as cardiac arrhythmias, postural hypotension, vertigo, weakness and electrolyte fluid disorders; And benzodiazepines mainly due to sedative and $\alpha$-adrenergic blockade ${ }^{(18)}$.

As shown, for the indicator Adequately using chairs, it was suggested by the experts' adjustments regarding their operational definition to become unique in the measurement of this indicator for prevention behavior. 
A study reports that inappropriate use of chairs establishes an unsafe environment that can lead to falls ${ }^{(17)}$. In this way, the chairs must be firm, provide support for the arms with adequate support, and to low padding and at a height that ensures the feet stay on the ground.

Thus, when observing the results of the validation of content, 17 of the 20 indicators belonging to the study were considered valid to evaluate the patient's health status regarding the prevention of falls behaviors in the hospital environment. Thus, it can be verified that most of the constitutive definitions, operational and operational magnitudes of the indicators for the NOC nursing result of fall prevention behavior obtained a statistically higher agreement rate than $85.0 \%$. Therefore, they were considered as valid as to the content by the experts and able to measure the construct fall prevention behavior in the hospital environment.

As a limitation of this study, there is the small number of specialists who accepted to participate in the evaluation of the instrument in an integral and timely manner.

\section{Conclusion}

When performing the content validation of the Nursing Outcome for Fall Prevention Behavior, it was found that the constitutive, operational definitions and operational magnitudes of the indicators were considered mostly clear, simple, intelligible, relevant, accurate, formed by appropriate expressions and enough to measure the risk of falls in hospitalized patients.

\section{Acknowledgement}

To the National Council of Scientific and Technological Development for the financing of the research. Process no 486043/2011-1.

\section{Collaborations}

Araújo JNM, Fernandes APNL and Vitor AF contributed to the project design, research execution, analysis, data interpretation, article writing, critical review of the intellectual content and final approval of the version to be published. Moura LA, Santos MMP and Ferreira Júnior MA contributed to the execution of the research, analysis, data interpretation and final approval of the version to be published.

\section{References}

1. Severo IM, Almeida MA, Kuchenbecker R, Vieira DFVB, Weschenfelder ME, Pinto LRC, et al. Risk factors for falls in hospitalized adult patients: an integrative review. Rev Esc Enferm USP [Internet]. 2014 [cited 2016 Dec 5]; 48(3):537-51. Available from:http://www.scielo.br/pdf/reeusp/ v48n3/0080-6234-reeusp-48-03-540.pdf

2. Abreu C, Mendes A, Monteiro J, Santos FR. Falls in hospital settings: a longitudinal study. Rev LatinoAm Enfermagem [Internet]. 2012 [cited 2016 Nov 27]; 20(3):597-603. Available from: http:// www.scielo.br/pdf/reeusp/v48n3/0080-6234reeusp-48-03-540.pdf

3. Correa AD, Marques IAB, Martinez MC, Laurino OS, Leão ER, Chimentão DMN. The implementation of a hospital's fall management protocol: results of a four-year follow-up. Rev Esc Enferm USP [Internet]. 2012 [cited 2016 Nov 27]; 46(1):6774. Available from: http://www.scielo.br/pdf/ reeusp/v46n1/en_v46n1a09.pdf

4. Luzia MF, Almeida MA, Lucena AF. Nursing care mapping for patients at risk of falls in the Nursing Interventions Classification. Rev Esc Enferm USP [Internet]. 2014 [cited 2016 Dec 2]; 48(4):63240. Available from: http://www.scielo.br/pdf/ reeusp/v48n4/0080-6234-reeusp-48-04-632.pdf

5. Abreu HCA, Reiners AAO, Azevedo RCS, Silva AMC, Abreu DROM, Oliveira AD. Incidence and predicting factors of falls of older inpatients. Rev Saúde Pública [Internet]. 2015 [cited 2017 Jan 18]; 49:37. Available from: http:// www.scielo.br/pdf/rsp/v49/0034-8910rsp-S0034-89102015049005549.pdf 
6. Prates CG, Luzia MF, Ortolan MR, Neves CM, Bueno ALM, Guimarães F. Falls in hospitalized adults: incidence and characteristics of these events. Cienc Cuid Saude [Internet]. 2014 [cited 2017 Jan 18]; 13(1):74-81. Available from: http://periodicos. uem.br/ojs/index.php/CiencCuidSaude/article/ viewFile/20728/pdf_145

7. Santana JS, Soares MJG. Bibliometric analysis of scientific production about validation. Rev Enferm UFPE on line [Internet]. 2014 [cited 2017 Jan 13]; 8(supl. 2):3594-9. Available from: http://www. revista.ufpe.br/revistaenfermagem/index.php/ revista/article/viewArticle/6180

8. Moorhead S, Johnson M, Maas M, Swanson E. Nursing Outcomes Classification (NOC). Missouri: Elsevier; 2013.

9. Almeida MA, Seganfredo DH, Barreto LNM, Lucena AF. Validation of indicators of the nursing outcomes classification for hospitalized adults at risk of infection. Texto Contexto Enferm [Internet]. 2014 [cited 2017 May 24]; 23(2):30917. Available from: http://www.scielo.br/pdf/ tce/v23n2/0104-0707-tce-23-02-00309.pdf

10. Sousa LMM, Marques-Vieira C, Caldevilla MNGN, Henriques CMAD, Severino SSP, Caldeira S. Instrumentos de avaliação do risco de quedas em idosos residentes na comunidade. Enferm Global [Internet]. 2016 [citado 2016 jan. 7]; 42:506-21. Disponível em: http://revistas.um.es/eglobal/ article/viewFile/230251/192621

11. Santos FPV, Borges LL, Menezes RL. Correlação entre três instrumentos de avaliação para risco de quedas em idosos. Fisioter Mov [Internet]. 2013 [citado 2016 dez. 12]; 26(4):883-94. Disponível em: www.scielo.br/pdf/fm/v26n4/a17v26n4.pdf

12. Costa-Dias MJM, Ferreira PL. Fall risk assessment tools. Rev Enf Ref [Internet]. 2014 [cited 2016 Jun 24]; IV(2):153-61. Available from: http:// rr.esenfc.pt/rr/index.php? module $=r$ \&target $=p u$ blicationDetails\&pesquisa $=\& i d \_a r t i g o=2456 \& i d$ revista $=24 \& i d \_$edicao $=66$
13. Medeiros RKS, Ferreira Júnior MA, Pinto DPSR, Vitor AF, Santos VEP, Barichello E. Modelo de validação de conteúdo de Pasquali nas pesquisas em Enfermagem. Rev Enf Ref [Internet]. 2015 [citado 2017 maio 24]; IV(4):127-35. Disponível em: http://www.scielo.mec.pt/scielo.php?script=sci_ arttext\&pid=S0874-02832015000100014

14. Lopes MVO, Silva VM, Araujo TL. Validação de diagnósticos de enfermagem: desafios e alternativas. Rev Bras Enferm [Internet]. 2013 [citado 2016 jun 16]; 66(5):649-5. Disponível em: http://www.scielo.br/scielo.php?script=sci_artte xt\&pid=S0034-71672013000500002

15. Monteiro DR, Pedroso MLR, Lucena AF, Almeida MA, Motta MGC. Studies on content validation in interface with the nursing classification systems: literature review. Rev Enferm UFPE on line [Internet]. 2013 [cited 2017 Feb 02]; 7(esp):41307. Available from: http://www.revista.ufpe.br/ revistaenfermagem/index.php/revista/article/ viewArticle/3034

16. Costa AGS, Oliveira ARS, Lopes MVO, Araujo TL. Concept analysis of behavior prevention in the context of chronic disease. Rev Enferm UERJ [Internet]. 2013 [cited 2016 Nov 8]; 21(1):6716. Available from: http://www.scielo.br/pdf/ reeusp/v48n4/0080-6234-reeusp-48-04-632.pdf

17. Moura LA, Araújo JNM, Fernandes APNL, Araújo MG, Silva AB, Olímpio JA, et al. Fall Prevention Behavior among Hospitalized Elderly Patients. Int Arch Med [Internet]. 2016 [cited 2017 May 24]; 9(57):1-9. Available from: http://imed.pub/ojs/ index.php/iam/article/view/1488

18. Rezende CP, Gaede-Carrillo MRG, Sebastião ECO. Queda entre idosos no Brasil e sua relação com o uso de medicamentos: revisão sistemática. Cad Saúde Pública [Internet]. 2012 [citado $2016 \mathrm{dez}$ 14]; 28(12):2223-35. Disponível em: http://www. scielo.br/pdf/csp/v28n12/02.pdf 